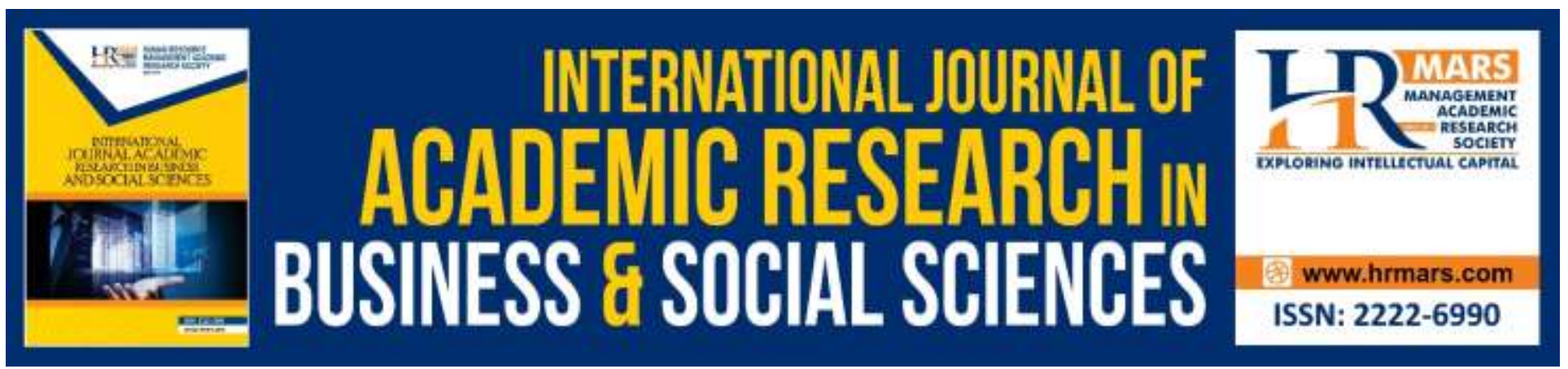

\title{
The Extent to Which Teachers of Islamic Education Practice the Competencies of Using Instructional Technology in Teaching the Secondary Stage in Jordan
}

Ahmed Mohamed Najadat, Mohammed A. Alomari

To Link this Article: http://dx.doi.org/10.6007/IJARBSS/v10-i6/7342

DOI:10.6007/IJARBSS/v10-i6/7342

Received: 12 April 2020, Revised: 25 May 2020, Accepted: 19 June 2020

Published Online: 29 June 2020

In-Text Citation: (Najadat \& Alomari, 2020)

To Cite this Article: Najadat, A. M., \& Alomari, M. A. (2020). The Extent to Which Teachers of Islamic Education Practice the Competencies of Using Instructional Technology in Teaching the Secondary Stage in Jordan. International Journal of Academic Research in Business and Social Sciences, 10(6), 675-695.

Copyright: (C) 2020 The Author(s)

Published by Human Resource Management Academic Research Society (www.hrmars.com)

This article is published under the Creative Commons Attribution (CC BY 4.0) license. Anyone may reproduce, distribute, translate and create derivative works of this article (for both commercial and non-commercial purposes), subject to full attribution to the original publication and authors. The full terms of this license may be seen

at: http://creativecommons.org/licences/by/4.0/legalcode

Vol. 10, No. 6, 2020, Pg. 675 - 695

http://hrmars.com/index.php/pages/detail/IJARBSS

JOURNAL HOMEPAGE

Full Terms \& Conditions of access and use can be found at http://hrmars.com/index.php/pages/detail/publication-ethics 


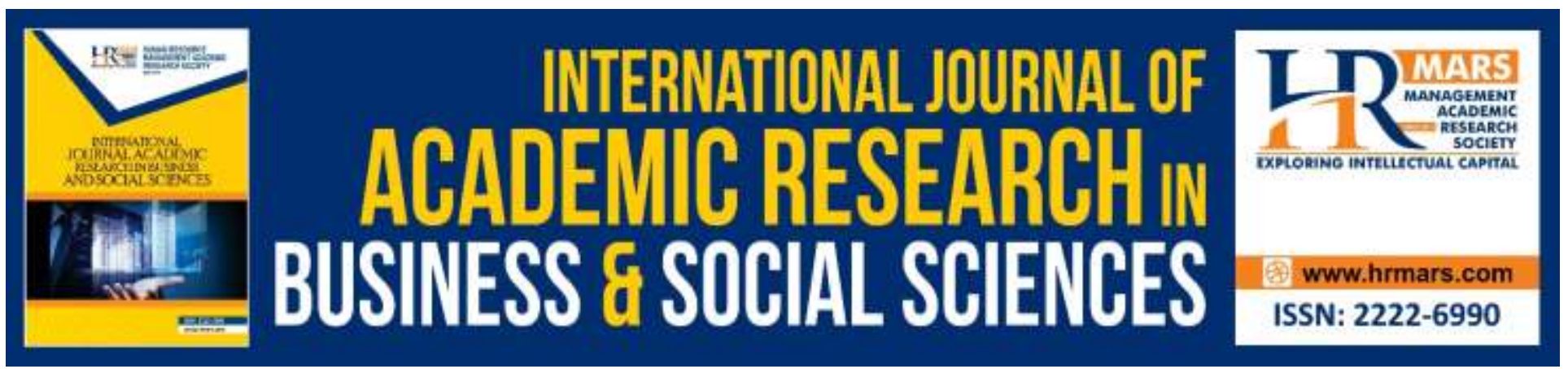

\title{
The Extent to which Teachers of Islamic Education Practice the Competencies of Using Instructional Technology in Teaching the Secondary Stage in Jordan
}

\author{
Ahmed Mohamed Najadat, Mohammed A. Alomari \\ Faculty Member, Assistant Professor, Department of Curriculum and Instruction, Faculty of \\ Education, Yarmouk University, Jordan.
}

\section{Abstract}

The aim of this study was to determine the extent to which Teachers of Islamic Education practice the competencies of using instructional technology in teaching the secondary stage from their point of view, The sample of the study consisted of 55 teachers of Islamic education belonging to the Directorate of Education of bani obeid in Irbid province; and a questionnaire of 50 competencies was prepared, distributed in 5 domains: Teaching and materials design, selection of instructional technology, use and operation of instructional technology, production of instructional technology, evaluation of instructional technology, data processed statistically. The results of the study showed that the degree of teachers' practice of instructional technology was moderate; and that there were no statistically significant differences at $\alpha=0.05$ in the degree of teachers' practice of instructional technology on all variables of the study.

Keywords: Islamic Education Teacher, High School, Teaching Techniques Qualifications, Jordan.

\section{Introduction}

The present era is characterized by rapid changes resulting from the technological development of technology and information technology (Mahafzah et al., 2020). so it has become necessary for the educational process to accompany these changes that have led to the restructuring of the education system and its institutions, and to change the goal of education from providing the learner with knowledge and facts to the need to acquire skills, capabilities, and self-reliance (al-Bourini et al., 2020). and the emergence of many new patterns and strategies to present content elements and components that changed the role of the teacher in receiving information and knowledge, designing means, drafting tests, to planning, organizing, and supervising the educational process (Al-Jawarneh, 2016). From this standpoint, many educational and educational institutions have been keen on integrating educational technologies in the teaching and learning process, and employing them to achieve their goals, and benefit from them within the classroom. The Islamic religion was concerned with the profession of education as an investment in the minds of individuals and in the development 
of their personalities in all its aspects (Al-Omari, et al., 2018). Also, Islamic educational thought scholars have emphasized the importance of the education profession and laid down rules, principles, and principles for teachers and learners, so that the teacher has a prominent place in society, and no one denies that The teacher helps build a strong generation that takes responsibility afterward and is a good, productive and productive citizen. It is worth noting that the teacher is the most important input to the educational learning process, the axis of the educational mission, and the main pillar in the success of the educational system and that for the roles he plays in achieving the intended educational outcomes, it helps learners to awareness of the problems of their societies and contribute to solving them, and accustom them to self-discipline and respect for others, Therefore, the educational and psychological sciences emphasized the necessity of preparing well-prepared scientific, cultural, professional and technological numbers (Al-Ajiz, 2007)

The interest in developing the skills and competencies of the teacher of Islamic education should be an urgent and fundamental issue, given the importance of the Islamic education curriculum and its continued impact on the lives of students; it develops the learner's thought, organizes his behavior, promotes his emotions, and achieves the goals of Islam in an individual's life (Al-Omari, et al., 2020). Whoever looks at the reality of Islamic education as an approach and teaching knows the difference between it and other subjects, as the usual teaching method prevails in teaching Islamic education, which reduces students' benefit from this subject and achieves the required goals (Al-Subaie, 2009) And since Islamic education is the basis of the renaissance of the Islamic nation and its goodness, and the reason for its strength and strength over the past eras; Therefore, the family, the mosque, and the school had a great impact in establishing the concepts of Islamic education among the members of society, in order to build a strong Muslim society with its strong ideas and morals, cherished by its history and achievements (Al-Fawares \& Bani Issa, 2015). Based on that, it is recognized. The teacher was able to have the necessary competencies that must be mastered to perform his educational and administrative tasks, in order to be able to carry out his work tasks. And proficiency is defined as "a tool to explore the capabilities, capabilities, and skills, of an employee, to employ him properly through the implementation of correct HR practices (Vaishya \& Srivastava, 2018).

It is defined as "capacity, ability, ability, capabilities, and skills, and it is the best level likely to be reached by an individual if he has the most appropriate training or education, and can be observed and measured, and make him able to achieve his goals in the best possible way: (Khazali \& Momani, 2010). It is also one of the ways in which the teacher's capabilities, skills, and quality in education can be considered, as it provides a framework for speaking about the basic characteristics a teacher is expected to possess (Aljawarneh \& Al-Omari, 2018).

The International Council of Standards for Training, Performance, and Instruction has defined a sufficiency as an integrated set of knowledge, skills, and trends that enables an individual to perform specific professional activities effectively, in accordance with the expected performance standards for the job (IBSTPI, 2006). The researchers believe that the educational competencies are the teacher having a set of capabilities, skills, and knowledge; to be well qualified to perform the educational function according to the prescribed standards. The researchers define it as "the ability, skill, or knowledge that a person must possess to perform a task assigned to him with an acceptable degree of mastery". There is no consensus about the number and type of primary and secondary teaching competencies as a result of the difference and diversity of educational visions and philosophies of education from one country to another (Aljawarneh \& Atan, 2018). Whatever the matter of this difference, the teacher's level of teaching competence and his level of practicing it remain among the 
INTERNATIONAL JOURNAL OF ACADEMIC RESEARCH IN BUSINESS AND SOCIAL SCIENCES Vol. 10, No. 6, June, 2020, E-ISSN: 2222-6990 @ 2020 HRMARS

main factors affecting the development of the effectiveness of the educational process in the school, and in the quality of its outputs (Quiran, 2008).

The Performance-Based Teacher Education (PBTE) movement has become one of the most prominent features of contemporary education and most common in educational circles interested in educating teachers in America and the practice derived from its theoretical framework has become an integrated movement with dimensions and its goal is theories of learning and education (Askar, 2008).

The use of educational techniques in an effective manner has helped the educational process; To solve many educational problems, as a result of the great role that these technologies play in developing the teaching process and facilitating learning and acquiring it in the least time and effort, such as: facing massive growth in knowledge, teaching large numbers of learners, and obtaining better learning for students (Al-Toudary, 2009). And when using techniques in education, the importance of the teacher increases and his role differs, contrary to what some think that e-learning will ultimately lead to dispensing with the teacher and canceling his role completely. Rather, education using techniques requires only a skilled teacher who is proficient in the methods and skills of e-learning, who can master his subject Alameya, who is willing to provide every hadith in his field of specialization (aljawarneh, 2018).

Educational techniques are defined as "a systematic application of the principles and theories of education scientifically in the actual reality of the field of learning, or it is the science of applying knowledge in educational purposes in an organized manner (Al-Da'abseh, et al., 2018). As for technological competencies, many studies (Bani Doumi, 2010: 254; Shatnawi, 2007; Alshare et al., 2020; Al-bdareen, 2020) have unanimously defined it as the set of knowledge, skills, and attitudes that a teacher possesses and is able to exercise in the field of educational techniques to achieve more effective learning that students enjoy (Alwagfi et al., 2020).

The use of the competencies of educational techniques in the educational process increases the efficiency of the educational position because it leads to raising the efficiency of the educational process, as it helps in saving time and effort and facing the shortage in preparing educationally qualified teachers, and encourages the activity and self and self-learning of learners, and providing various methods and methods in education In a manner commensurate with the individual differences between learners and the conditions of their education, diversification of the reinforcement methods in a way that motivates the learner to continue in the process of attaining and acquiring a skill, making friction between the learner and what he learns is direct and effective contact, and providing more potential, energy, efficiency and effectiveness for the educational process (Muhammad et al., 2004). From this standpoint, the importance of the topic of integrating technologies with learning in a significant way has emerged in the current period, and the need to pay attention to models of educational technologies, such as computers and its applications in education, and to learning resource centers, educational satellite television stations, distance learning, and other technological materials and devices, as a result of the great role She plays in improving and improving the educational process (Al-Jamlan, 2004; Al-Bdareen \& Khasawneh, 2019). Based on the foregoing, it is possible to point out the importance of employing modern and multiple technologies in teaching Islamic education. The importance of this material and its impact on different aspects of life, and its clear role in guiding members of society and their directions, as Islamic education focused on the individual and the family, and noted the roles of science and learning, and diversified generous verses in the methods of research and investigation; To access the information, 
she urged thinking and thinking, and benefiting from the experiences of the other, which denies taking lessons and learning from them (Al-Musa \& Al-Abed, 2016).

Many studie (Todari, 2009) have indicated that the use of technologies in education has become a strategic choice and it is an urgent necessity in light of the recent technological revolution and the communications revolution, which means the inability to dispense It is in all fields of education, which requires the necessity of qualifying and preparing teachers professionally to qualify them to deal with these modern technologies, and the necessity of having the competencies of educational techniques. Considering the importance of technologies in education, it has become necessary to introduce these techniques into the educational system in the educational process and in the field of teaching Islamic education, especially in the secondary school grades, so this study came to reveal the degree of the practice of Islamic education teachers in the secondary stage in Jordan for the competencies of educational techniques.

Considering the importance of using the competencies of educational techniques, its role in improving the quality of education, and its ability to make a qualitative leap in the preparation and rehabilitation of teachers; Educational and educational institutions of various levels try to benefit from e-learning in solving problems facing the educational process to keep pace with technological development, and it is noticeable that the programs for preparing and qualifying Islamic education teachers in the second stage are free of some electronic educational competencies, and the lack of their exercise in these competencies during teaching despite their importance Each of them has an educational position and needs, as it aims to evaluate the knowledge, attitudes, and skills necessary to make teachers able to master learning according to pre-determined educational outcomes.

The researchers noted through their work as a faculty member at the university, teaching curriculum materials and methods of teaching Islamic education materials and teaching technology materials for undergraduate and higher diploma students, and overseeing many student teachers in-field training, and on teachers of Islamic education and computer at the model school at the university for a number of the years; Noting that there is a weakness in the practice of Islamic education teachers in the secondary and other stages of the competencies of educational techniques, and this confirms, what was recommended by many studies in the light of its results, such as a study (Merdas, 2014; Mando, 2016; Al-Hyari \& Ansibu, 2018) by holding courses in The field of educational techniques in teaching performance in order to reach the desired goal, and what was recommended by some studies, such as (Mando, 2016) study by applying a real evaluation related to educational techniques to extract all the needs of teachers, all this prompted the researchers to conduct such a study

The importance of the study comes from the importance and role of the Islamic education teacher in the educational process, if the teacher is the cornerstone of the educational process, and through it learners acquire knowledge, directions and learning skills, so the importance of the study lies in the following, providing a clear vision of the importance and effectiveness of modern technologies in developing and improving the process Educational and saving elements: time, effort, and money to take appropriate action in light of this perception. Providing feedback to individuals of the study sample and those responsible for the educational process in identifying the most prominent modern technology applications that can be employed in the Ministry of Education, and about the needs for teachers regarding the use of technologies, and in instructing teachers' awareness of the importance of the competencies of educational techniques, and contributing to increasing their practice of them. Benefiting from the results of the study in the process of developing teacher preparation programs 
INTERNATIONAL JOURNAL OF ACADEMIC RESEARCH IN BUSINESS AND SOCIAL SCIENCES

Vol. 10, No. 6, June, 2020, E-ISSN: 2222-6990 @ 2020 HRMARS

in educational institutions through the orientation towards educational technologies, and the development of in-service teacher training tools on the basis of the competencies of educational technologies and actual needs, so that they achieve their desired goals and in line with modern guidance in education. Promote studies Previous in the field of competencies of educational techniques for teachers, and opened the way for other studies seeking to determine the competencies of educational techniques necessary for teachers in general.

\section{Literature Review}

Within the limits of their knowledge, the researchers reached a set of previous studies that are directly related to the current study and can be reviewed from the oldest to the most recent: Mirdas (2014) conducted a study aimed at defining the e-learning competencies of Islamic education teachers in the secondary stage in the State of Kuwait. The survey descriptive approach was used and the sample consisted of 105 teachers. The questionnaire was used as a study tool whose validity and reliability was verified. One of the most important results were that there is a severe weakness in the ability of teachers to plan and design any educational software or use electronic tests to evaluate students in e-learning. Mando (2016) conducted a study aimed at identifying the degree of class teachers in the Hama governorate with the competence of educational technology from their point of view. The descriptive-analytical method was used, the sample consisted of 85 male and female teachers, and a questionnaire consisting of 59 items was prepared. The results showed the low level of the teachers 'level of competency practice, and the presence of statistically significant differences in the range of practice due to the gender variable and in favor of males, and the absence of statistically significant differences in the range of practice due to the variable of educational qualification. Al-Andawi (2017) also conducted a study aimed at identifying the degree of geography teachers practicing for the basic stage, graduates of technological competencies in the fourth Amman Soil Directorate from their point of view. The descriptive approach was used. The study sample consisted of 87 male and female teachers. The results showed that the degree of teachers' exercise of competencies came average in all areas of the tool as a whole, and the absence of statistically significant differences in the extent of the practice is attributable to the variable of experience and qualification, and the presence of statistically significant differences in the extent of the practice attributed to the gender variable on the field of competencies of designing lessons for the benefit of teachers. Al-Asheeri (2017) conducted a study that sought to know the degree of separation system teachers in public schools in the Kingdom of Bahrain in terms of technological competencies for elearning. The descriptive approach was used, and the study sample consisted of 223 male and female teachers. The study concluded that teachers' possession of the competencies of designing lessons electronically came with a high degree, and the competencies of using educational technology for elearning came in a medium degree, and the competences of using the computer came in a low degree, and the absence of statistically significant differences in the degree of ownership attributable to the gender variable and job experiences, and the presence of a positive and positive relationship between Internet use and lesson design competencies. The invasion and Alimat (2017) also conducted a study aimed at knowing the degree of teaching staff members in Jordanian universities practicing technological competencies from their point of view. The descriptive method was used, a questionnaire was prepared and applied to 563 faculty members. The study concluded that the teaching staff members 'practice of competencies was of a moderate degree, and the presence of statistically significant differences in the range of practice is attributable to the academic rank and in 
INTERNATIONAL JOURNAL OF ACADEMIC RESEARCH IN BUSINESS AND SOCIAL SCIENCES Vol. 10, No. 6, June, 2020, E-ISSN: 2222-6990 @ 2020 HRMARS

favor of the rank of professor, and the absence of statistically significant differences in the extent of practice attributable to the variable of specialization and the type of university in all competencies. Al-Youssef (2017) conducted a study aimed at revealing the degree to which Islamic education teachers in Amman Governorate possess the competencies of using smart technology in education. The sample of the study consisted of 175 male and female teachers. To achieve the objectives of the study, a questionnaire consisting of 35 items was developed. The results of the study concluded that the degree of Islamic education teachers possessing the competencies of using smart technology in education was medium, and that there were statistically significant differences in the degree of ownership attributable to the variables of the educational qualification and years of experience and in favor of the higher educational qualification and years of more experience, and that there were no differences due to the gender variable. Al-Hyari \& Anshebo (2018) carried out a study that sought to know the extent of the awareness of the faculty members at the Faculty of Educational Sciences at the University of Jordan to enable them to educational competencies within the principles of comprehensive quality. The descriptive method was used, and the study tool consisted of a questionnaire distributed to a sample of 50 faculty members. The study showed that the awareness of faculty members to enable them to achieve competencies came in a high degree, and there were no statistically significant differences attributable to the variable of gender and experience. Sajit (2018) conducted a study aimed at revealing the teaching competencies necessary for Islamic education teachers from the viewpoint of their teachers, the research sample consisted of 75 teachers, from the Directorate of Education in Dhi Qar Governorate In Iraq, they were chosen intentionally, and the descriptive approach was adopted, and to achieve the objectives of the study A questionnaire was developed consisting of a paragraph distributed into four areas: lesson planning, teaching aids, teaching methods, and evaluation. The results of the study showed that the Teaching competencies required for Islamic education teachers from the viewpoint of their teachers and on all areas of study were medium, and also showed differences in the gender variable for male sex.

Lucero (2018) conducted a study aimed at determining the level of educational competence of teachers based on educational work cells. The researcher used the descriptive method, and the study sample included 85 male and female teachers in the Philippines. The results of the study showed that the general level of educational competence of the teacher is very high; In the areas of planning and evaluation in school curricula; In the competencies of education; In family and community participation; And in professional culture. Educational working cell sessions can be designed that will focus on areas with low results in order to address the weakness of these competencies. Al-Shboul study (2013) came to identify the degree of availability of technological competencies necessary for faculty members in Jordanian universities and the obstacles to their availability. A descriptive survey method was used. The sample consisted of 390 faculty members who were randomly selected, and a questionnaire consisting of 40 items was developed. The results showed that the degree of availability and practice of competencies is high and that the degree of obstacles is low.

It appears from the presentation of previous studies that all of these studies dealt with the efficiencies of educational techniques in general, and some of them dealt with the degree of possession of these competencies by teachers, while others focused on the degree of their exercise such as the study (Rokaya \& Al-Ghazzawi, 2018; Mando, 2016; Al-Lundawi, 2017), while studies were conducted to reveal the degree of teachers' possession of these competencies as a study (El Ashry, 2017), and studies were conducted with the purpose of identifying the technological competencies necessary for teachers such as the study (Merdas, 2014; Al-Badarin \& Al-Azzeam, 2017), and others 
INTERNATIONAL JOURNAL OF ACADEMIC RESEARCH IN BUSINESS AND SOCIAL SCIENCES

Vol. 10, No. 6, June, 2020, E-ISSN: 2222-6990 @ 2020 HRMARS

were conducted with the purpose of detecting The availability of these competencies among university faculty. This study is distinguished from the previous studies mentioned in this study, as it will search for the degree of Islamic education teachers practicing the competencies of educational techniques in the educational process.

\section{Methodology}

This current research investigates the potential of the extent to which teachers of Islamic education practice the competencies of using instructional technology in teaching the secondary stage in Jordan. The researchers distributed a self-administrated questionnaire (Alwagfi et al., 2020). A deductive approach was adapted to collect specific quantitative information to accept or reject the hypothesis.

To achieve the two goals of the study, the two researchers followed the descriptive approach to its suitability of the nature of the study and its goals. The study community was represented in the teachers of Islamic education at the secondary stage working in the Directorate of Education for Major General Bani Ubaid in Irbid Governorate, where the number of members of that community reached 55 male and female teachers, including 30 male and female teachers, and they represented the study community and sample simultaneously; Because the population of the study population is relatively small, and Table 1 shows the distribution of the sample population according to demographic characteristics.

Table 1. Description of study sample characteristics

\begin{tabular}{llll}
\hline Variables & Category & Repetition & Percentage \\
\hline \multirow{4}{*}{ Gander } & Teacher & 25 & 45.5 \\
& female teacher & 30 & 54.5 \\
& Total & 55 & 100.0 \\
\hline \multirow{4}{*}{ qualification } & Bachelor & 24 & 43.6 \\
& postgraduate & 31 & 56.4 \\
& Total & 55 & 100.0 \\
\hline \multirow{5}{*}{ experiences } & Less than 5 years & 7 & 12.7 \\
& 5-10years & 20 & 36.4 \\
& More than 10 years & 28 & 50.9 \\
& Total & 55 & 100.0 \\
\hline
\end{tabular}

Based on the availability of educational literature related to the sources and references related to Islamic education and its curricula, educational techniques and previous studies and educational research, the researchers designed a list of the competencies of the educational techniques required for Islamic education teachers in the secondary stage, arranged and organized in the form of a questionnaire to determine the degree of teacher practice for it, formed In its initial form of 60 sufficiency, distributed over 5 fields: the field of teaching design and educational materials 13 sufficiency, the field of selecting educational technologies 14 sufficiency, the field of using and operating educational technologies 12 sufficiency, the field of production of educational materials and programs 11 adequacies, and the field of evaluation 10 adequacies.

The content of the tool was verified by presenting it to a group of arbitrators, chosen from the Yarmouk University professors, including 5 specialists in Islamic education curricula and methods and 
5 specialists in educational techniques, with the aim of judging the degree of suitability of the paragraph, its clarity, its affiliation to the domain, and the integrity of language formulation. Some changes have been made in the linguistic wording, and some paragraphs have been modified based on the observations and proposals of $80 \%$ of the arbitrators, and the tool has become in its final form consisting of two parts: the first: general data related to the individuals of the sample, in terms of gender, educational qualification, job experiences, and the second: It consists of 50 educational technology sufficiency, formulated in the form of items that were graded according to the Lekart fivepoint scale (very large, large, medium, few, and very few). These competencies were distributed in 5 areas, namely: The field of teaching design and educational materials 11 sufficiency and the field of choice of educational techniques is 13 sufficiency, the field of using and operating educational technologies is 8 sufficiency, the field of production of educational materials and programs is 8 sufficiency, and the field of evaluation is 10 sufficiency. The researchers conducted a test of the internal consistency of the study tool's vertebrae, through the calculation of Cronbach's alpha Coefficient, since the Cronbach alpha method depends on the consistency of the individual's performance from one vertebra to another, and it indicates the strength of bonding and cohesion between the vertebrae of the scale, in addition to that the alpha coefficient Provides good grade of stability. Although there are no standard rules regarding the appropriate values for the Cronbach alpha-factor, in practice it $\alpha=0.50$ is reasonable in research related to management and humanities.

Table 2: Internal Consistency Coefficient

\begin{tabular}{lll}
\hline Domain & paragraphs & $\begin{array}{l}\text { Cronbach } \\
\text { Alpha }\end{array}$ \\
\hline $\begin{array}{l}\text { Teaching design and teaching materials } \\
\text { The selection of educational techniques }\end{array}$ & 11 & 0.89 \\
$\begin{array}{l}\text { Efficiency in the use and operation of } \\
\text { educational techniques }\end{array}$ & 8 & 0.87 \\
$\begin{array}{l}\text { Efficiency for the production of } \\
\text { educational techniques }\end{array}$ & 8 & 0.80 \\
Evaluation efficiency & 10 & 0.84 \\
\hline All & 50 & 0.86 \\
\hline
\end{tabular}

From Table 2, it appears that the Cronbach alpha coefficients for the fields of study ranged between 0.80-0.89, the highest for the field of "teaching design competencies and teaching materials", and the lowest for the field of "competencies for the use and operation of educational techniques", and the Cronbach alpha coefficient for the tool as a whole was 0.95; All stability parameters are high and acceptable for the purposes of the study, as the stability factor (Cronbach alpha) is acceptable for the purposes of this study.

\section{Results Discussion}

The first question: What is the degree of the practice of Islamic education teachers in the secondary stage of the competencies of educational techniques from their point of view?

To answer this question, the researchers extracted the arithmetic averages and the standard deviations for the paragraphs of the fields of practice of Islamic education teachers in the second stage for the competencies of educational techniques, as follows: 
INTERNATIONAL JOURNAL OF ACADEMIC RESEARCH IN BUSINESS AND SOCIAL SCIENCES

Vol. 10, No. 6, June, 2020, E-ISSN: 2222-6990 @ 2020 HRMARS

Table 3. Averages and Standard Deviations

\begin{tabular}{lccl}
\hline Domain & $\mathrm{M}$ & SD & $\begin{array}{l}\text { Relative } \\
\text { importance }\end{array}$ \\
\hline design & 3.16 & .58 & Medium \\
choice & 3.11 & .58 & Medium \\
Use and & 3.22 & .58 & Medium \\
operation & & .66 & Medium \\
$\begin{array}{l}\text { Production } \\
\text { Evaluation }\end{array}$ & 2.52 & .54 & Medium \\
\hline
\end{tabular}

Table 3 shows that all fields came with a moderate degree, as the design competencies came first With a mean average of 3.16 and a standard deviation of 0.58 , the field of choice came in second place with an average of 3.11 and a standard deviation of 0.58 , the field of use and operation came third with an average of 3.22 and a standard deviation of 0.58 , the field of production came in fourth place with an average of 2.52 and a standard deviation of 0.66 , and the evaluation came in the fifth and last rank with an average Mathematical 2.90 and standard deviation 0.54.

The researchers consider that the average degree obtained by the estimates of Islamic education teachers about their practice of the competencies of educational techniques in teaching is a satisfactory result, although it may seem to many researchers that they are few and there must be increased interest in this matter or else the science and the learner are lost, and this result may be attributed to many Among the factors, the most important of which is that many teachers of specialization consider that the Islamic education subject is a theoretical subject and do not need technical means to help in understanding it, in addition to these teachers not knowing how to use educational techniques and apply them in this process, in addition to these teachers did not receive Adequate training, guidance and encouragement necessary to develop their skills and competencies necessary for the practice of employing educational techniques in education.

This result was in agreement with the results of the study (Al-Asheeri, 2017; Al-Ghazwat and Alimat, 2017; Mando, 2016; Al-Windawi, 2017), whose results all showed that the degree of practicing or using the competencies of educational techniques in education was medium, and differed with the result of a study (Amayrah, 2019; Al-Youssef, 17; Lucero, 2018) whose results showed a high degree of practice.

Arithmetic averages and standard deviations for teaching design competencies and teaching material competencies are arranged in descending order, and Table 4 shows that. 
INTERNATIONAL JOURNAL OF ACADEMIC RESEARCH IN BUSINESS AND SOCIAL SCIENCES Vol. 10, No. 6, June, 2020, E-ISSN: 2222-6990 @ 2020 HRMARS

Table 4. Averages and standard deviations of design and teaching materials

\begin{tabular}{|c|c|c|c|c|c|}
\hline Rank & $\begin{array}{l}\text { Numbe } \\
r\end{array}$ & paragraph & $M$ & SD & $\begin{array}{l}\text { Relative } \\
\text { improbit } \\
\text { y }\end{array}$ \\
\hline 1 & 7 & $\begin{array}{l}\text { Recognize the importance of simplicity and clarity in } \\
\text { the design of educational technologies. }\end{array}$ & 3.49 & 0.77 & Medium \\
\hline 2 & 8 & $\begin{array}{l}\text { Ensure the provision of excitement and attract the } \\
\text { learners' attention to educational technology }\end{array}$ & 3.49 & 0.74 & Medium \\
\hline 3 & 1 & $\begin{array}{l}\text { Analyzing Islamic education curricula to determine } \\
\text { their needs for educational materials, tools and } \\
\text { devices }\end{array}$ & 3.40 & 1.05 & Medium \\
\hline 4 & 10 & $\begin{array}{l}\text { Define appropriate educational methods and } \\
\text { strategies to achieve the desired goals }\end{array}$ & 3.27 & 0.76 & Medium \\
\hline 5 & 9 & $\begin{array}{l}\text { Observing the conditions that must be met when } \\
\text { designing educational techniques }\end{array}$ & 3.25 & 0.77 & Medium \\
\hline 6 & 3 & $\begin{array}{l}\text { Analyze the characteristics of learners to determine } \\
\text { appropriate educational techniques and educational } \\
\text { program }\end{array}$ & 3.11 & 0.79 & Medium \\
\hline 7 & 2 & $\begin{array}{l}\text { Analysis of educational goals to determine } \\
\text { appropriate educational techniques to achieve each } \\
\text { goal }\end{array}$ & 3.05 & 0.89 & Medium \\
\hline 8 & 4 & $\begin{array}{l}\text { Taking into account the nature of educational } \\
\text { experiences when designing educational techniques. }\end{array}$ & 2.98 & 0.78 & Medium \\
\hline 9 & 6 & $\begin{array}{l}\text { Consider the possibility of producing educational } \\
\text { techniques from the materials in the learner's } \\
\text { environment. }\end{array}$ & 2.95 & 0.87 & Medium \\
\hline 10 & 5 & $\begin{array}{l}\text { Define the components and parts of educational } \\
\text { technology. }\end{array}$ & 2.91 & 0.87 & Medium \\
\hline 11 & 11 & $\begin{array}{l}\text { Developing varied and alternative activities to take } \\
\text { into account individual differences between learners. }\end{array}$ & 2.80 & 0.97 & Medium \\
\hline \multicolumn{3}{|c|}{ Overall rate } & 3.16 & 0.58 & Medium \\
\hline
\end{tabular}

Table 4 shows that the arithmetic mean for the field paragraphs, teaching design competencies and teaching materials ranged between 2.80-3.49, the highest was for paragraph 7 with an average of 3.49 and an average degree, and came at the last rank of paragraph No. 11 which with an average of 2.80 and an average degree, and the average for the field as a whole was 3.16 and a degree Medium. This result may be attributed to the fact that Islamic education teachers are mostly graduates of Sharia faculties, and they are often not eligible to teach in schools, so this reason seems to have affected their possession of educational competencies in general and the competencies of designing educational materials in particular, and the result of this study agreed With the results of a study (Merdas, 2014; Allendawi, 2017), it differed with the results of a study (Al-Asheri, 2017; Lucero, 2018). Arithmetic averages and standard deviations for the paragraphs in the choice of educational techniques were given in descending order, and Table 5 shows that. 
INTERNATIONAL JOURNAL OF ACADEMIC RESEARCH IN BUSINESS AND SOCIAL SCIENCES

Vol. 10, No. 6, June, 2020, E-ISSN: 2222-6990 @ 2020 HRMARS

Table 5: averages and standard deviations of educational techniques selection

\begin{tabular}{|c|c|c|c|c|c|}
\hline Rank & Number & paragraph & $M$ & SD & $\begin{array}{l}\text { Relative } \\
\text { improbity }\end{array}$ \\
\hline 1 & 7 & $\begin{array}{l}\text { Taking into account the element of security } \\
\text { and safety when choosing educational } \\
\text { techniques. }\end{array}$ & 3.62 & 0.93 & Medium \\
\hline 2 & 8 & $\begin{array}{l}\text { Choose the right teaching techniques that } \\
\text { achieve educational goals. }\end{array}$ & 3.36 & 0.83 & Medium \\
\hline 3 & 9 & $\begin{array}{l}\text { Choose the right teaching techniques for } \\
\text { educational content. }\end{array}$ & 3.33 & 0.80 & Medium \\
\hline 4 & 12 & $\begin{array}{l}\text { Learning sourcing available in the } \\
\text { environment. }\end{array}$ & 3.2 & 1.01 & Medium \\
\hline 5 & 10 & $\begin{array}{l}\text { Choose the appropriate teaching techniques } \\
\text { for teaching methods and strategies. }\end{array}$ & 3.13 & 0.80 & Medium \\
\hline 6 & 2 & $\begin{array}{l}\text { Identify the characteristics of educational } \\
\text { techniques and their ability to attract the } \\
\text { attention of learners. }\end{array}$ & 3.11 & 0.90 & Medium \\
\hline 7 & 4 & $\begin{array}{l}\text { Taking into account the material cost and the } \\
\text { extent to which educational technology can } \\
\text { be used more than once. }\end{array}$ & 3.11 & 0.92 & Medium \\
\hline 8 & 11 & $\begin{array}{l}\text { Engaging learners in the selection of } \\
\text { educational techniques. }\end{array}$ & 3.09 & 0.97 & Medium \\
\hline 9 & 13 & $\begin{array}{l}\text { Taking into account the inclusion of the } \\
\text { educational technique on one specific idea } \\
\text { commensurate with the requirements of the } \\
\text { educational situation. }\end{array}$ & 3.00 & 1.02 & Medium \\
\hline 10 & 3 & $\begin{array}{l}\text { Taking into account the availability of the } \\
\text { element of modernity and scientific accuracy } \\
\text { in the content of educational technology. }\end{array}$ & 2.98 & 0.95 & Medium \\
\hline 11 & 5 & $\begin{array}{l}\text { Determine the right time to use educational } \\
\text { technology. }\end{array}$ & 2.95 & 0.87 & Medium \\
\hline 12 & 1 & $\begin{array}{l}\text { Observe the criteria and conditions for the } \\
\text { selection of educational materials. }\end{array}$ & 2.91 & 0.87 & Medium \\
\hline 13 & 6 & $\begin{array}{l}\text { Determine the type and size of the display and } \\
\text { viewing area suitable for all learners. }\end{array}$ & 2.67 & 1.14 & Medium \\
\hline \multicolumn{3}{|c|}{ Overall } & 3.11 & .577 & Medium \\
\hline
\end{tabular}

Table 5 shows that the mathematical averages for the field paragraphs, "Competencies for Selecting Educational Techniques" ranged between 2.67-3.62, the highest of which was for Paragraph No.), which states "Observing the element of safety and security when choosing educational techniques." With an average mathematical average of 3.62 and with a moderate degree, and in last rank paragraph No. 6, which states "Specifying the type and size of the display and the appropriate viewing area for all learners" with an average score of 2.67 and an average degree, and the 
INTERNATIONAL JOURNAL OF ACADEMIC RESEARCH IN BUSINESS AND SOCIAL SCIENCES Vol. 10, No. 6, June, 2020, E-ISSN: 2222-6990 @ 2020 HRMARS

mathematical average for the whole field is 3.11 and with a medium degree. The researchers can confirm that the main reason that will be repeated in every field of study is that the qualification of these teachers was based on the understanding that they will not turn to the profession of education but rather to other areas such as public speaking, preaching and guidance, Islamic banks, and Sharia courts. The researchers did not have any study on the competencies of choosing educational techniques, by comparing it with this result.

Mathematical averages and standard deviations for the paragraphs in the field of use and operation of educational techniques are given in descending order, and Table 6 shows that.

Table 6: Computational averages and standard deviations of the field of efficiency paragraphs for the use and operation of educational techniques

\begin{tabular}{|c|c|c|c|c|c|}
\hline Rank & Number & paragraph & $M$ & SD & $\begin{array}{l}\text { Relative } \\
\text { improbity }\end{array}$ \\
\hline 1 & 1 & $\begin{array}{l}\text { Prepare learners' minds to use educational } \\
\text { technology. }\end{array}$ & 3.53 & 0.81 & Medium \\
\hline 2 & 4 & $\begin{array}{l}\text { Use the school's internet as a renewable } \\
\text { source of information. }\end{array}$ & 3.33 & 0.92 & Medium \\
\hline 3 & 3 & $\begin{array}{l}\text { Creating educational attitudes to the use of } \\
\text { educational techniques. }\end{array}$ & 3.31 & 0.81 & Medium \\
\hline 4 & 2 & $\begin{array}{l}\text { Experience educational technology before } \\
\text { using it. }\end{array}$ & 3.24 & 0.92 & Medium \\
\hline 5 & 5 & $\begin{array}{l}\text { Make sure that the educational technology } \\
\text { of all learners is clear while using it. }\end{array}$ & 3.24 & 0.92 & Medium \\
\hline 6 & 6 & $\begin{array}{l}\text { Allow learners to use educational } \\
\text { technology. }\end{array}$ & 3.16 & 0.92 & Medium \\
\hline 7 & 7 & $\begin{array}{l}\text { Follow the performance and learning of } \\
\text { learners while using educational technology. }\end{array}$ & 3 & 0.86 & Medium \\
\hline 8 & 8 & $\begin{array}{l}\text { Discuss and evaluate educational technology } \\
\text { with learners after use. }\end{array}$ & 2.98 & 1.03 & Medium \\
\hline \multicolumn{3}{|c|}{ Overall } & 3.22 & .583 & Medium \\
\hline
\end{tabular}

Table 6 shows that the arithmetic mean for the paragraphs of the field "efficiencies in the use and operation of educational techniques" ranged between 2.38-3.53, the highest of which was paragraph 1 with an average score of 3.53 and an average degree, and at last rank paragraph No. 8 with an average score of 2.98 and an average degree, and the average score for the field as a whole was 3.22 And to a moderate degree. This may be due to the course plans developed by the colleges of Sharia or Islamic Studies, which did not take into account the students 'acquisition of teaching techniques, as they do not focus on the teaching process in the first place. This result was in agreement with the result of the study (Al-Asheeri, 2017), which confirmed that the level of Islamic education teachers' use of educational techniques was average.

Arithmetic averages and standard deviations for the paragraphs in the field of production of educational techniques are given in descending order, and Table 7 shows that. 
INTERNATIONAL JOURNAL OF ACADEMIC RESEARCH IN BUSINESS AND SOCIAL SCIENCES Vol. 10, No. 6, June, 2020, E-ISSN: 2222-6990 @ 2020 HRMARS

Table 7: Computational averages and standard deviations of the field of efficiency in the production of educational techniques are arranged downwardly

\begin{tabular}{llllll} 
Rank & Number & paragraph & M & SD \\
\hline 1 & $\begin{array}{l}\text { Production of educational computer software. } \\
2\end{array}$ & 2.71 & 0.94 & Medium \\
2 & $\begin{array}{l}\text { Production of different models, samples and } \\
\text { educational models. }\end{array}$ & 2.62 & 0.83 & Medium \\
3 & $\begin{array}{l}\text { Production of various educational plates } \\
\text { (electrical, wild, pockets, magnetic, news.). }\end{array}$ & 2.58 & 0.88 & Medium \\
4 & $\begin{array}{l}\text { Producing educational films using a video camera. } \\
\text { Production of educational bags for educational }\end{array}$ & 2.58 & 0.96 & Medium \\
5 & $\begin{array}{l}\text { units. } \\
6\end{array} \quad \begin{array}{l}\text { Producing educational audio tapes. } \\
7\end{array} \quad \begin{array}{l}\text { Production of photographs. } \\
\text { Modify some commercially produced methods in }\end{array}$ & 2.05 & Medium \\
8 & $\begin{array}{l}\text { Mdvance. } \\
\text { Overall }\end{array}$ & 2.38 & 1.02 & Medium \\
\hline
\end{tabular}

It appears from Table 7 that the arithmetic mean for the paragraphs of the field "the competencies of producing educational techniques" ranged between 2.29-, the highest of Paragraph 1 was with an average of 2.71 and an average degree, and at the last rank paragraph No. 8 with an average of 2.29 and a low degree, and the average for the field as a whole was 2.52 and an intermediate degree. The researchers attribute this to the fact that the production of educational technologies needs skills that the teacher must acquire while he is on the study seat by studying courses in the production of educational methods and their techniques and this is what the academic plans of these teachers lack, as the researchers examined the study schedules of the colleges of Sharia and Islamic Studies and they did not find something like that. This result is consistent with the results of the study (Al-Asheri, 2017; Al-Wandi, 2017; Al-Youssef, 2017), and it differed with the result of a study (Mirdas, 2014) that confirmed weakness in production efficiencies, and with a study (Mando, 2016; Lucero, 2018), that showed a high score on production efficiencies.

Mathematical averages and standard deviations for the assessment competency items were sorted in descending order, and Table 8 shows that. 
INTERNATIONAL JOURNAL OF ACADEMIC RESEARCH IN BUSINESS AND SOCIAL SCIENCES Vol. 10, No. 6, June, 2020, E-ISSN: 2222-6990 @ 2020 HRMARS

Table 8 Arithmetic averages and standard deviations of the evaluation area paragraphs

\begin{tabular}{|c|c|c|c|c|c|}
\hline Rank & Number & paragraph & $M$ & SD & Rank \\
\hline 1 & 1 & $\begin{array}{l}\text { Use different types to evaluate educational } \\
\text { techniques (before, constructive, and final). }\end{array}$ & 3.13 & 0.75 & Medium \\
\hline 2 & 6 & $\begin{array}{l}\text { Determine the ability of teaching techniques to } \\
\text { contribute to addressing individual differences. }\end{array}$ & 3.05 & 0.73 & Medium \\
\hline 3 & 2 & $\begin{array}{l}\text { Collaborate with learners in evaluating materials in } \\
\text { terms of: design, production, and operation. }\end{array}$ & 3.04 & 0.77 & Medium \\
\hline 4 & 3 & $\begin{array}{l}\text { Identify problems in the process of producing, } \\
\text { selecting and using learning techniques in the } \\
\text { classroom. }\end{array}$ & 2.93 & 0.74 & Medium \\
\hline 5 & 5 & $\begin{array}{l}\text { Use evaluation results to improve and increase the } \\
\text { effectiveness of educational technology. }\end{array}$ & 2.93 & 0.81 & Medium \\
\hline 6 & 9 & $\begin{array}{l}\text { Determining the accuracy, up-to-date accuracy and } \\
\text { accuracy of educational technology information and } \\
\text { its ability to present information clearly. }\end{array}$ & 2.93 & 0.74 & Medium \\
\hline 7 & 8 & $\begin{array}{l}\text { Determining the ability of educational technologies } \\
\text { to achieve educational goals for learners. }\end{array}$ & 2.91 & 0.65 & Medium \\
\hline 8 & 7 & $\begin{array}{l}\text { Evaluation of the available resources available to the } \\
\text { teacher on educational techniques such as } \\
\text { publications, publications, guides and means }\end{array}$ & 2.76 & 0.82 & Medium \\
\hline 9 & 10 & $\begin{array}{l}\text { To assess the success of ready-made (commercially } \\
\text { available) educational techniques in achieving the } \\
\text { objectives of the Islamic Education Curriculum. }\end{array}$ & 2.75 & 0.87 & Medium \\
\hline 10 & 4 & $\begin{array}{l}\text { Design forms and cards for evaluating educational } \\
\text { techniques. }\end{array}$ & 2.56 & 1.14 & Medium \\
\hline Overa & & & 2.90 & .54 & Medium \\
\hline
\end{tabular}

From Table 8, it appears that the mathematical averages for the paragraphs of "evaluation efficiencies" ranged between 2.56-3.13, the highest of which was Paragraph 1 with an average of 3.13 and an average score, and in the last rank Paragraph 4 with an average of 2.56 and an average degree, and the average for the field as a whole was 2.90 and an intermediate degree. And it seems that the main reason for that is also the lack of training of these teachers during the study on the use of techniques in teaching, and this in turn is linked to the evaluation of their use as the evaluation is linked to use permanently, and the evaluation is an important part of the teaching of the use of technologies in education. This result was consistent with the results of the study (Al-Asheri, 2017), and this result differed with the results of the study (Merdas, 2014)

The researchers believe that the general result of the study, and the result of each field of study, and the result of each paragraph of the study, which always came with a medium degree, has come medium and not low as expected despite the multiple reasons that confirm that this class of teachers does not receive the education necessary to produce and use Techniques in education, and the reason for this is that most of these teachers have a long experience in teaching (see Table 1), which 
INTERNATIONAL JOURNAL OF ACADEMIC RESEARCH IN BUSINESS AND SOCIAL SCIENCES Vol. 10, No. 6, June, 2020, E-ISSN: 2222-6990 @ 2020 HRMARS

gives them some skills that they may have learned from their peers in other educational specializations, or because some of them undergo training courses held by the Ministry of Education for newly appointed learners in Its schools.

The second question: Are there statistically significant differences at the level of significance $\alpha=0.05$ in the degree of the practice of Islamic education teachers in the secondary stage of the competencies of educational techniques due to the variables (gender, educational qualification, and job experiences)?

To answer this question, the researchers used the $T$ test for independent samples to find the differences between the average degree of Islamic education teachers practicing in the secondary stage for the competencies of educational techniques according to gender, and Table 9 shows that.

Table 9: Results of independent sample test analysis to find differences between the average degrees of practice of Islamic education teachers in secondary school for the adequacy of educational techniques by gender

\begin{tabular}{|c|c|c|c|c|c|c|}
\hline Domain & gender & No & $\mathbf{M}$ & SD & $\mathbf{T}$ & Sig \\
\hline \multirow[b]{2}{*}{ Teaching design and teaching materials } & \multirow{2}{*}{$\begin{array}{l}\text { Teacher } \\
\text { female } \\
\text { teacher }\end{array}$} & 25 & 3.09 & .44 & & \multirow[b]{2}{*}{.484} \\
\hline & & 30 & 3.21 & .68 & .705 & \\
\hline \multirow[b]{2}{*}{ The selection of educational techniques } & \multirow{2}{*}{$\begin{array}{l}\text { Teacher } \\
\text { female } \\
\text { teacher }\end{array}$} & 25 & 3.10 & .48 & & \multirow[b]{2}{*}{.848} \\
\hline & & 30 & 3.13 & .65 & .192 & \\
\hline \multirow{2}{*}{$\begin{array}{l}\text { Efficiency in the use and operation of educational } \\
\text { techniques }\end{array}$} & \multirow{2}{*}{$\begin{array}{l}\text { Teacher } \\
\text { female } \\
\text { teacher }\end{array}$} & 25 & 3.18 & .46 & - & \multirow[b]{2}{*}{.584} \\
\hline & & 30 & 3.26 & .68 & .550 & \\
\hline \multirow[b]{2}{*}{ Efficiency to produce educational techniques } & \multirow{2}{*}{$\begin{array}{l}\text { Teacher } \\
\text { female } \\
\text { teacher }\end{array}$} & 25 & 2.46 & .76 & & \multirow[b]{2}{*}{.512} \\
\hline & & 30 & 2.58 & .58 & $\begin{array}{l}- \\
.661\end{array}$ & \\
\hline \multirow[b]{2}{*}{ Evaluation efficiency } & \multirow{2}{*}{$\begin{array}{l}\text { Teacher } \\
\text { female } \\
\text { teacher }\end{array}$} & 25 & 2.90 & .50 & & \multirow[b]{2}{*}{.979} \\
\hline & & 30 & 2.90 & .58 & $\begin{array}{l}- \\
.027\end{array}$ & \\
\hline \multirow[b]{2}{*}{ Technology efficiency as a whole } & \multirow{2}{*}{$\begin{array}{l}\text { Teacher } \\
\text { female } \\
\text { teacher }\end{array}$} & 25 & 2.94 & .38 & & \multirow[b]{2}{*}{.590} \\
\hline & & 30 & 3.01 & .55 & .543 & \\
\hline
\end{tabular}

Table 9 shows the results of the test analysis to reveal the differences between the average degree of Islamic education teachers practice in the secondary stage for the competencies of educational techniques at the level of significance $\alpha=0.05$ depending on the gender (teacher, female teacher), the results showed that there were no statistically significant differences for the degree of the practice of Islamic education teachers The competencies of educational techniques depending on the gender variable, and on the scale as a whole. This is due to the fact that the teachers of Islamic education have studied in the same educational institutions, and have undergone the same educational programs in those institutions, and they are teaching in schools that have similar conditions with their technical and technical capabilities, and they have been subjected to one 
INTERNATIONAL JOURNAL OF ACADEMIC RESEARCH IN BUSINESS AND SOCIAL SCIENCES Vol. 10, No. 6, June, 2020, E-ISSN: 2222-6990 @ 2020 HRMARS

training course for males and females. This result was consistent with the results of the study (AlHyari and Anseibo, 2016; Al-Asheeri, 2017; Al-Youssef, 2017), and it differed with the results of a study (Mando, 2016; Allendawi, 2017) that confirmed the existence of significant differences on the gender variable in favor of males in the study (Mando, 2016) and for females in a study (Al-Windawi, 2017). This difference may be attributed to the difference in the year in which the two studies were conducted, and the difference in the location of the two studies may have had a role as well.

A separate sample T-test was used to find the differences between the average degree of Islamic education teachers practicing at the secondary level for the competencies of educational techniques according to the academic qualification (Bachelor, Postgraduate), and Table 10 shows that.

Table 10. Results of the analysis of the qualifications of educational techniques according to the scientific qualification

\begin{tabular}{|c|c|c|c|c|c|c|}
\hline Domain & Qualification & No & M & SD & $\mathbf{T}$ & Sig \\
\hline \multirow{2}{*}{ The selection of educational techniques } & Bachelor & 24 & 3.16 & .74 & \multirow{2}{*}{.083} & \multirow{2}{*}{.934} \\
\hline & Postgraduate & 31 & 3.15 & .43 & & \\
\hline \multirow{2}{*}{$\begin{array}{l}\text { Efficiency in the use and operation of } \\
\text { educational techniques }\end{array}$} & Bachelor & 24 & 3.13 & .71 & \multirow{2}{*}{.255} & \multirow{2}{*}{.800} \\
\hline & Postgraduate & 31 & 3.09 & .46 & & \\
\hline \multirow{2}{*}{ Efficiency to produce educational techniques } & Bachelor & 24 & 3.30 & .68 & \multirow{2}{*}{.827} & \multirow{2}{*}{.412} \\
\hline & Postgraduate & 31 & 3.17 & .41 & & \\
\hline \multirow{2}{*}{ Evaluation efficiency } & Bachelor & 24 & 2.64 & .67 & \multirow{2}{*}{1.089} & \multirow{2}{*}{.281} \\
\hline & Postgraduate & 31 & 2.44 & .66 & & \\
\hline \multirow{2}{*}{ Technology efficiency as a whole } & Bachelor & 24 & 2.93 & .65 & \multirow{2}{*}{.370} & \multirow{2}{*}{.713} \\
\hline & Postgraduate & 31 & 2.87 & .46 & & \\
\hline \multirow{2}{*}{ The selection of educational techniques } & Bachelor & 24 & 3.03 & .60 & \multirow{2}{*}{.670} & \multirow{2}{*}{.506} \\
\hline & Postgraduate & 31 & 2.94 & .36 & & \\
\hline
\end{tabular}

Table 10 shows the results of the test analysis to reveal the differences between the average degree of Islamic education teachers practicing in the second stage for the competencies of educational techniques at the level of significance $(\alpha=0.05)$ according to the educational qualification (Bachelor and Postgraduate studies), the results of the study showed that there are no significant differences Statistics of the degree to which Islamic education teachers practice the competencies of educational techniques according to the educational qualification and on the scale as a whole. Returning to the academic schedules in the graduate programs in the colleges of Sharia and Islamic Studies; The researchers found that there were also no teaching courses in either the masters or doctoral programs concerned with educational techniques, which may be attributed to the absence of differences between those holding bachelor's degrees and those with higher degrees in the same specialty. The results of this study were in agreement with the results of the study (Mando, 2016; Allendawi, 2017) and differed with the results of the study (Al-Youssef, 2017), which confirmed the existence of differences and in favor of the higher qualification.

To answer this question, the researchers used the mono-variance analysis test to find the differences between the average degree of Islamic education teachers practicing at the secondary level for the competencies of educational techniques according to job experiences (less than 5 years, 5-10 years, 11 years or more), and table 11 shows that. 
INTERNATIONAL JOURNAL OF ACADEMIC RESEARCH IN BUSINESS AND SOCIAL SCIENCES Vol. 10, No. 6, June, 2020, E-ISSN: 2222-6990 @ 2020 HRMARS

Table 11: Results of the analysis of competencies of educational techniques according to job experiences

\begin{tabular}{|c|c|c|c|c|c|c|}
\hline Domain & Cumulative rate & No & $\mathbf{M}$ & SD & $\mathbf{F}$ & Sig \\
\hline \multirow{3}{*}{ The selection of educational techniques } & Less than 5 years & 7 & 2.94 & .42 & \multirow{3}{*}{2.11} & \multirow{3}{*}{.131} \\
\hline & $5-10$ years & 20 & 3.02 & .68 & & \\
\hline & More than 11 years & 28 & 3.31 & .51 & & \\
\hline \multirow{3}{*}{$\begin{array}{l}\text { Efficiency in the use and operation of } \\
\text { educational techniques }\end{array}$} & Less than 5 years & 7 & 2.90 & .36 & \multirow{3}{*}{2.51} & \multirow{3}{*}{.091} \\
\hline & $5-10$ years & 20 & 2.95 & .57 & & \\
\hline & More than 11 years & 28 & 3.28 & .59 & & \\
\hline \multirow{3}{*}{$\begin{array}{l}\text { Efficiency in the use and operation of } \\
\text { educational techniques }\end{array}$} & Less than 5 years & 7 & 2.91 & .48 & \multirow{3}{*}{2.09} & \multirow{3}{*}{.134} \\
\hline & $5-10$ years & 20 & 3.14 & .60 & & \\
\hline & More than 11 years & 28 & 3.36 & .57 & & \\
\hline \multirow{3}{*}{$\begin{array}{l}\text { Efficiency } \\
\text { techniques }\end{array}$} & Less than 5 years & 7 & 2.73 & .27 & \multirow{3}{*}{.48} & \multirow{3}{*}{.619} \\
\hline & $5-10$ years & 20 & 2.44 & .65 & & \\
\hline & More than 11 years & 28 & 2.53 & .74 & & \\
\hline \multirow{3}{*}{ Evaluation efficiency } & Less than 5 years & 7 & 2.61 & .41 & \multirow{3}{*}{1.45} & \multirow{3}{*}{.244} \\
\hline & $5-10$ years & 20 & 2.86 & .54 & & \\
\hline & More than 11 years & 28 & 2.99 & .56 & & \\
\hline \multirow{3}{*}{ Technology efficiency as a whole } & Less than 5 years & 7 & 2.82 & .33 & \multirow{3}{*}{1.66} & \multirow{3}{*}{.201} \\
\hline & $5-10$ years & 20 & 2.88 & .46 & & \\
\hline & More than 11 years & 28 & 3.09 & .50 & & \\
\hline
\end{tabular}

Table 11 shows the results of the test analysis to reveal the differences between the average degree of Islamic education teachers practicing in the second stage for the competencies of educational techniques at the level of significance $\alpha=0.05$ depending on job experiences less than 5 years, 5-10 years, 11 years or more, where the results showed that there were no Statistical differences for the degree to which Islamic education teachers exercise the competencies of educational techniques according to the variable of functional experiences and on the scale as a whole. This is also due to the fact that the time spent by the teacher in the educational process does not necessarily provide him with technical expertise because this type of experience requires training courses and programs in a practical way and does not acquire experience. This result was consistent with the results of the study (Al-Asheeri, 2017; Al-Wendawi, 2017; Al-Hayari and Insebu, 2016), and contradicted the results of the study (Al-Youssef, 2017) that showed differences in favor of the long experience category.

\section{Conclusions \& Recommendations}

In light of the study experience, and based on its results, the researchers concluded the following: The degree of Islamic education teachers practicing the competencies of educational techniques in education was average. There were no statistical differences at the level of significance $(\alpha=0.05)$ for any of the study variables.

Recommendations and suggestions: In light of the results of the study, the researchers recommend the following: Urging teachers of Islamic education at the secondary level to increase interest in their practice of the competencies of educational techniques in the educational process because of their great role in developing knowledge and scientific and technological competencies .Enriching the 
INTERNATIONAL JOURNAL OF ACADEMIC RESEARCH IN BUSINESS AND SOCIAL SCIENCES

Vol. 10, No. 6, June, 2020, E-ISSN: 2222-6990 @ 2020 HRMARS

programs for preparing teachers in universities in cooperation with the Ministry of Education in educational technology courses to develop their competencies and how to apply them in teaching .The development of integrated training programs by the Ministry of Education to train teachers during service and repeatedly on the optimal use of the competencies of educational techniques in teaching. Conducting more studies in the field of teaching technology competencies for teachers and practicing them in the field.

\section{References}

Al-Asheri, H. (2017). Degree of teachers in the public schools in the Kingdom of Bahrain owning the technological competencies of e-learning. Journal of Educational Sciences, 25 (3), 251-282.

Al-Badarin, R. Q., \& Al-Azzeam, A. H. (2017). Job design and its impact on the job strain: Analysing the job as a moderating variable in the private hospitals in Irbid. International Journal of Humanities and Social Science, 7(3), 152-168.

Al-bdareen, R. (2020). The Impact of the Administrative Empowerment on the Employees Performance Management Process. International Journal of Asian Social Science, 10(4), 193-206.

Al-Bdareen, R., \& Khasawneh, H. (2019). Human resources staffing process and its impact on job involvement: Irbid District Electricity Company as a case study. Problems and Perspectives in Management, 17(2), 254.

Al-Bourini, F. A., Aljawarneh, N. M., Bourini, I., Almaaitah, M. F., \& Alomari, K. A. (2020). Directing Strategic Decision and Perceived Faculty Performance Using PLS Analysis and Monte Carlo Simulation in Jordanian Private Universities. Journal of Talent Development and Excellence, 12(3s), 2235-2252.

Al-Da'abseh, T., Aljawarneh, N., \& Shwiyat, Z. (2018). Marketing Mix Strategies and Its Impact on Organizational Performance Efficiency in the Jordanian Company for Investment and Supply-Safeway: An Empirical Study. Invention Journal of Research Technology in Engineering \& Management, 2(2), 14-23.

Al-Hazmi, H. M. (2018). The reality and constraints of the use of faculty members at the Faculty of Education at Umm Al Qura University for the Internet in scientific research. Journal of The Iraqi University, 41(3), 279-334.

Al-Jawarneh, N. M. S. (2016). Case Study: Business Management School at the Turkish Republic of North Cyprus and how Strategic Thinking and Planning Can Improve the Performance of the Organization to Maintain Stable between Competitors.

Aljawarneh, N. M. S., \& Atan, T. (2018). Linking Tolerance to Workplace Incivility, Service Innovative, Knowledge Hiding, and Job Search Behavior: The Mediating Role of Employee Cynicism. Negotiation and Conflict Management Research, 11(4), 298-320.

Aljawarneh, N., \& Al-Omari, Z. (2018). The Role of Enterprise Resource Planning Systems ERP in Improving Customer Relationship Management CRM: An Empirical Study of Safeway Company of Jordan. International Journal of Business and Management, 13(8), 86-100.

Al-Omari, Z. S., Aljawarneh, N., Davut, S., \& Salah, A. (2018). The Impact of Marketing Mix Elements on Forming Mental Images About Islamic Banks in Jordan: An Empirical Study. OFFICIAL, 12,54 . 
INTERNATIONAL JOURNAL OF ACADEMIC RESEARCH IN BUSINESS AND SOCIAL SCIENCES

Vol. 10, No. 6, June, 2020, E-ISSN: 2222-6990 @ 2020 HRMARS

Al-Omari, Z., Alomari, K., \& Aljawarneh, N. (2020). The role of empowerment in improving internal process, customer satisfaction, learning and growth. Management Science Letters, 10(4), 841-848.

Al-Saadoun, (2012). Investigations in the methods of Islamic education and methods for its evaluation. Al-Ustaz Magazine, (203): 1136-1113

Alshare, F., Aljawarneh, N., Alomari, K., Alomari, Z., Albdareen, R., AAlwagfi, A., \& Alradaideh, A. (2020). Factors influencing cellular device purchase decisions in Jordan. Management Science Letters, 10(11), 2501-2506.

Al-Shboul, M. (2013). The Level of E-Learning Integration at the University of Jordan: Challenges and Opportunities. International Education Studies, 6(4), 93-113.

Alwagfi, A. A., Aljawarneh, N. M., \& Alomari, K. A. (2020). Work Ethics and Social Responsibility: Actual and Aspiration. Journal of Management Research, (12)1, 26-36.

Askar, Alaa (2008). Educational competencies and their role in developing the performance of future teachers. Kirkuk University Journal for Humanities Studies, 3 (2), 174-195.

IBSTPI. (2006). Instructor competencies. Retrieved. 12 October 2019, From: Khazali, Qassem and Momani, Abdul Latif (2010). Teaching competencies of lower secondary school teachers in private schools in light of variables of educational qualification and years of experience and specialization. Damascus University Journal 26 (3): 553-592.

Korthagen, J. (2004). In search of the essence of a good teacher: towards a more holistic approach in teacher education. Teaching and teacher Education, 20, 77-97.

Lucero, J. (2018). Instructional competence of teachers: basis for learning action cell sessions. International Journal of Novel Research in Education and Learning, 5 (4): 5-8.

Mahafzah, A. G., Aljawarneh, N. M., Alomari, K. A. K., Altahat, S., \& Alomari, Z. S. (2020). Impact of customer relationship management on food and beverage service quality: The mediating role of employees satisfaction. Humanities \& Social Sciences Reviews, 8(2), 222-230.

Majid. (2004). Teaching Islamic Education: Theoretical Foundations and Practical Methods. Amman: Al Masirah House for Publishing and Distribution.

Mando, R. (2016). The degree to which class teachers in Hama governorate practice educational technology competencies from their point of view. PhD thesis published in Al-Baath University Journal, 38 (10), 45-75.

Merdas, K. (2014). E-learning competencies for teachers of Islamic education at the secondary level in the State of Kuwait. University educational and psychological studies in Zagazig, 85 (2), 41-96.

Moein. (2004). The extent to which modern education and information technology can be incorporated into the education system in the Kingdom of Bahrain from the viewpoint of the scholars of the Bachelor of Education and Information Technology Program at the University of Bahrain. Journal of Educational and Psychological Sciences, 5 (2): 97-127.

Rokaya, A. L., \& Al-Ghazzawi, H. (2018). Diversity training and its impact on the employees' organizational commitment: job satisfaction as a moderating variable in the Classic Fashion Apparel Industry company. International Journal of Business and Management, 13(10).

Shatnawi, Abdul Karim. (2007). The educational competencies of female teachers are specialized in a field (scientific and literary) teacher at the College of Education in Ibri / Sultanate of Oman from the viewpoint of cooperating teachers in Al Dhahir South School. Journal of Educational and Psychological Studies, 1 (1), 119-158. 
INTERNATIONAL JOURNAL OF ACADEMIC RESEARCH IN BUSINESS AND SOCIAL SCIENCES

Vol. 10, No. 6, June, 2020, E-ISSN: 2222-6990 @ 2020 HRMARS

The Saudi, Khaled (2011). The extent of the use of linguistic competence by Islamic education teachers in Tafila Governorate. Jordanian Journal of Educational Sciences, 7 (3), 289-302.

Vaishya, R., Jha, S., \& Srivastava, D. (2018). Development of Managerial Competency Scale: A Telecom Sector Study. Indian Journal of Industrial Relations, 54 (2): 321-333. 